\title{
THE SCOPE OF FIRST AMENDMENT PROTECTION FOR GOOD-FAITH DEFAMATORY ERROR
}

\author{
In 1964 the United States Supreme Court imposed a constitutional
} limitation on the power of the states to award libel damages to public officials falsely defamed by critics of their official conduct. This limit was established in New York Times $v$. Sullivan, ${ }^{1}$ where the court held that the first amendment's free speech protection required

a federal rule that prohibits a public official from recovering damages for a defamatory falsehood relating to his official conduct unless he proves that the statement was made with "actual malice" -that is, with knowledge that it was false or with reckless disregard of whether it was false or not. ${ }^{2}$

Attempts to apply this privilege to cases not involving public officials have led to considerable difficulty in measuring the scope of this new protection. The Supreme Court's decision in Rosenblatt v. Baer ${ }^{3}$ is the most recent example of the courts' inept handling of the privilege. The primary reason for the difficulty is that the courts adhere to the "public official" language of Times and fail to examine libel suits involving good faith defamatory error in terms of the purposes of first amendment protection.

In Times, the Public Safety Commissioner of Montgomery, Alabama sued the New York Times for publishing statements in a political advertisement soliciting funds for the defense of Martin Luther King, $\mathrm{Jr}^{4}$ The advertisement described numerous acts of repression by

1. 376 U.S. 254 (1964).

2. Id. at 279-80. Three Justices-Black, Douglas, and Goldberg-concurred in the result, but felt the privilege accorded to critics of official public conduct should be absolute; i.e., that even defamatory falsehoods knowingly made should be privileged. The scope of this Note is limited to the proper applicability of the qualified, good-faith privilege as set down in Times, although it is recognized that the concept of "actual malice" will be difficult to apply. See, e.g., Henry v. Collins, 380 U.S. 356 (1965).

3. 86 Sup. Ct. 669 (1966).

4. King had recently been indicted for perjury. The relevant paragraphs of the ad stated:

In Montgomery, Alabama, after students sang "My Country, 'Tis of Thec" on the State Capital steps their leaders were expelled from school and truckloads of policc armed with shotguns and tear-gas ringed the Alabama State College Campus. When the entire student body protested to state authorities by refusing to re-register, their dining hall was padlocked in an attempt to starve them into submission ..... Again and again the Southern violators have answered Dr. King's peaceful protests with intimidation and violence. They have bombed his home almost killing his wife 
"Southern violators" against Negro demonstrators. Alleging that the entire list of charges about these violators could be read as referring to him in his role as police commissioner, Sullivan demanded a retraction and then instituted suit. Some of the statements were proven to be false, ${ }^{6}$ and the jury awarded Sullivan the full $\$ 500,000$ claimed. The Alabama Supreme Court affirmed. It restated a position held by a majority of states prior to this case: that the common law privilege of "fair comment," which protected statements about matters of general public concern, did not apply to misstatements of fact, but only to expressions of opinion. ${ }^{7}$

The U.S. Supreme Court unanimously reversed the judgment, holding that the first amendment required a federal rule protecting good faith defamatory error about the official conduct of public officials regardless of whether the error was made in a statement of fact or opinion. In so holding, the Court declared that the basic purpose of the first amendment was to guarantee full and free exchange on public issues. This guarantee necessarily included protection of the right to make "caustic and sometimes unpleasantly sharp attacks on government and public officials."' Without immunity for inadvertent error, "wouldbe critics of official conduct might be deterred from voicing their criticism" for fear of having to prove their statements true.

The Times opinion explicitly declined to discuss what was included

and child. They have assaulted his person. They have arrested him seven times-for "speeding," "loitering," and similar "offenses." And now they have charged him with "perjury"-a felony under which they could imprison him for ten ycars. (Emphasis in original).

The ad was signed by various members of the "Committec to Defend Arartin Luther King and the Struggle for Freedom in the South." N.Y. Times, Miarch 29, 1960, p. 24. The ad is set out in the Appendix of the Times opinion, 376 U.S. at 292.

5. The lawyers for the Times asked for clarification from Sullivan, because they vere "puzzled" as to how the ad referred to him. Sullivan did not answer. At the trial, six witnesses testified they had read the ad as referring to plaintiff in his role as Public Safety Commissioner. Id. at 258. See also Pierce, The Anatomy of an Historic Decision: New York Times Co. v. Sullivan, 43 N.C.L. REv. 315, 321 (1965).

6. Among the errors: King was arrested four times and not seven; the ascault was an unproven incident; the police had not "ringed" the campus (but had been deployed in large numbers); most of the students had returned to classes the next day; and the dining room had not been padlocked. Plaintiff was also permitted to show he had committed no bombings or assaults on the theory that the entire list of charges in the ad could be read as referring to him. 376 U.S. at 259. The disturbing implications of this method of proving false statements never directed at a plaintiff in the first place are discussed in Kalven, The New York Times Case: A Note on "The Central Meaning of the First Amendment," 1964 Supreare Court Rev. 191, 198-99 (1964).

7. New York Times Co. v. Sullivan, 274 Ala. 656, 149 So. $2 d 25$ (1963).

8. 376 U.S. at 270. 
in the categories of "official conduct" or of "public official." It is apparent, however, that first amendment protection for good faith defamatory error cannot be confined to the "official conduct of public officials" scope of Times. The opinion itself recognized that a broadening of the privilege would be inevitable. ${ }^{10}$ And barely four months later, the Court in Garrison v. Louisiana ${ }^{11}$ moved outside the official conduct category by holding that a privilege was also applicable to criticism "which might touch on an official's fitness for office ..."12 even if the criticism was also personally defamatory.

Further, the purpose of the first amendment, as defined in Times and elsewhere, precludes a limited scope for the privilege. The Supreme Court in Times marshalled an array of historical and precedential authority to support the proposition that the first amendment reflects "a profound national commitment to the principle that debate on public issues should be uninhibited, robust, and wide-open." ${ }^{13}$ Throughout, the opinion reaffirmed broad concepts of the first amendment's reach. The Court noted the "general proposition that freedom of expression upon public questions is secured by the First Amendment"14 and endorsed Justice Brandeis' concept of the free speech principle that "public discussion is a political duty [and] . . . that it is hazardous to discourage thought, hope, and imagination ... that the path of safety lies in the opportunity to discuss freely supposed grievances and proposed remedies...."15

A series of first amendment cases buttresses the Times opinion's premise that free speech protection secures free expression on all public issues. More than 25 years ago the Court held that the goal of free speech was "that men may speak as they think on matters vital to them" and that discussion of "all matters of public concern without previous restraint or fear of subsequent punishment" was a prime function of the first amendment. ${ }^{16}$

This concept of free speech strongly suggests that the "official conduct of public officials" category is part of, but not the limit of, the area of speech which should be protected by the new privilege. Issues in

\section{Id. at $283, \mathrm{n} .23$.}

10. Ibid.

11. 379 U.S. 64 (1964).

12. Id. at 77 .

13. 376 U.S. at 270-71. (Emphasis added).

14. Id. at 269.

15. Id. at 270, citing Brandeis, J., concurring in Whitney v. Calif., 274 U.S. 357 , 875.76 (1927).

16. Thornhill v. Alabama, 310 U.S. 88, 95, 101-2 (1940). 
which the public has a legitimate concern are not confined to exchanges on an official level. Debate between private persons about the wisdom, consequence, and worth of ideas is a vital part of the political and social process. If this area of debate is to be "robust, wideopen, and uninhibited,"17 good faith defamatory errors made in discussions about public issues should be privileged whether or not one of the participants in the debate, or the object of the discussion, is a public official.

To state that the first amendment protects speech about "public issues" is not to advance a proposition in a vacuum. Courts have long had to determine whether a remark was of public, as opposed to purely private, concern under the fair comment privilege. ${ }^{18}$ Under this privilege, courts protect defamatory expressions of opinion from libel actions when the expressions deal with "those matters which are of legitimate concern to the community ... because they materially affect the interest of all the community." 19 Such items as the management of public institutions, the conduct of private enterprise affecting the general community, and the performance of those who submit their talents to the public for approval have been held to be matters in which the public has a legitimate concern..$^{20}$ The courts can use this body of experience in defining public issues even though the fair comment doctrine developed independently of first amendment holdings. ${ }^{21}$ Both the fair comment doctrine and the first amendment reflect the principle that individuals are not to be punished for speaking out on matters about which they and the community at large have a legitimate interest. The Times opinion itself relied on a noted fair comment decision in extending protection for defamatory falsehoods about public officials as a Constitutional matter. ${ }^{22}$

17. See 376 U.S. at 278.

18. Prosser, Torts, \& 110, p. 812 (3d ed. 1964). See also 1 Harper \& Jasies, Torts, \$ 5.28, pp. 456.57 (1956); Hallen, Fair Comment, 8 TexAs L. Rev. 41 (1929). Various jurisdictions use the "fair comment" doctrine in different ways. Some, for cxample, use it to distinguish cases in which a complainant must prove damages, rather than having the court presume damage from publication. The suggested use of fair comment here is limited to the utility of the doctrine in delineating public, as opposed to private, defamation.

19. Prosser, op. cit. supra at 812. The majority of jurisdictions held that the privilege applied only to expressions of opinion, and not to misstatements of fact. Prosers at 814. I HARPER \&: JAMIEs, op. cit. supre at 458; Restatearent, ToRTs $\$ 606$ comment b (1938). The distinction has been most difficult to apply. Titus, Statement of Fact Versus Stalement of Opinion-A Spurious Dispute in Fair Comment, 15 VANo. I. REv. 1203 (1952).

20. Prosser, op. cit. supra note 19, and cases compiled therein.

21. The Times opinion is the first attempt to impose a Constitutional requirement for such a privilege. Previously, state court analyses were made in terms of the common law of the jurisdiction.

22. See, e.g., the Times reliance on Coleman v. MacLennon, 78 Kan. 711, 98 P. 281 
The lower courts which have attempted to apply the Times doctrine, however, have tried to work within the language of the case, rather than to implement the first amendment principles implicit in the opinion. They have almost uniformly sought to apply or withhold the privilege on the basis of whether the complainant was enough like a public official to warrant the application of the Times rule.

An indication of this trend appeared in Gilberg $v$. Goffi. ${ }^{23}$ Gilberg, a law partner of the Mayor of Mount Vernon, sued the defendant for remarks made during the local election. Goffi, a candidate for local office, had charged in a speech and in a letter to the local paper that Gilberg's firm was engaged in legal practices which amounted to a conflict of interests. ${ }^{24}$ In dismissing the complaint, the New York Appellate Division held that Gilberg's cause of action was "so closely related" to a complaint based on criticism of a public official that he had "no justiciable cause of action." The court reasoned that Gilberg, "having entered the fray as champion of [his] law firm, . . . made himself as much a part of the local political campaign as did his law partner, the Mayor."25

The opinion in Pearson v. Fairbanks Publishing Co.20 provides a more extreme statement equating active private citizens with "public officials." Syndicated columnist Drew Pearson sued the owner of an Alaska newspaper for publishing editorials which announced the cancellation of Pearson's columns and called him "the garbage man of the fourth estate." The editorials charged that almost "every single thing he ever said about Alaska has been inaccurate in whole or in part." The court noted that the controversy arose during an election campaign in which plaintiff and defendant had supported opposing candidates. Since the Times rule clearly extended to candidates for public office, the court found

no reasonable basis to exempt those who presume to speak for such candidates, particularly those public figures of international stature ... [Pearson], a public figure and internationally known newspaperman and radio columnist of no mean proportion, should occupy the same standing in the law of libel as Senator Gruening, whose cause he was publicly supporting. There can be little ques-

(1908), a noted fair comment case applying a privilege for defamatory falschoods, quoted in 376 U.S. at $280-82$.

23. 21 App. Div. 2d 517, 251 N.Y.S.2d 823 (1964).

24. The charge was made in the course of a campaign discussion on the need for a local ordinance prohibiting conflict of interest situations.

25. 251 N.Y.S.2d at 831 .

26. 33 U.S.L. WEEK 2307 (Alaska Super. Ct., Nov. 25, 1964).

27. Pearson v. Fairbanks Publishing Co. Appendix B (original unreported opinion). 
tion that candidate Gruening could have been so assailed with impunity.... If Senator Gruening could be attacked, so could one of his outspoken supporters. ${ }^{28}$

In its most recent libel case, the Supreme Court also made the complainant's status the central relevant inquiry. In Rosenblatt $v$. Baer, $_{20}$ a case tried before the Times decision, the former supervisor of a New Hampshire county recreation area was awarded damages on the basis of a column in a local newspaper praising the new management. Commenting on the "tremendous difference in net cash result," Rosenblatt had written, "What happened to all the money last year? and every other year?" 30 The Supreme Court remanded the case for a new trial in order to determine whether or not the statement should be protected by the principles of Times. The Court thought there were two fundamental principles, "first, a strong interest in debate on public issues, and second, a strong interest in debate about those persons who are in a position significantly to influence the resolution of those issues." 31 In spite of the recognition that there is an interest in free debate about public officials and public affairs, the Court did not direct the trial court to determine not whether the statement was made concerning a public issue, but to determine only whether the complaining party was a public official. Perhaps the Supreme Court viewed the "public official" and "public issue" categories as coterminous. ${ }^{32}$ But in any event the inquiry required by the Court in Rosenblatt is an inept one to implement the policies of the first amendment.

The use of the "public official" classification may lead to the protection of good-faith statements which falsely defame an individual and which serve no public purpose justifying a first amendment privilege. Once the public official label attaches to an individual almost any statement about him might be privileged. In Garrison v. Loutisiana, the first libel case after Times, the Supreme Court said:

[a]ny criticism of the manner in which a public official performs his duties will tend to affect his private, as well as his public reputation. The New York Times rule is not rendered inapplicable merely because an official's private reputation, as well as his

28. Id. at 5. The confusion in the opinion is partially indicated by the citations of the Times case, which privileges good-faith errors, and the Restatement of Torts, which does not.

29. 86 Sup. Ct. 669 (1966).

30. Id. at 672 .

31. Id. at 675 .

32. The opinion stated that a non-Times definition of malice "is constitutionally insufficient where discussion of public affairs is concerned." Id. at 8. (Emphasis added.) 
public reputation, is harmed. The public official rule protects the paramount public interest in a free flow of information to the people concerning public officials, their servants. To this end, anything which might touch on an official's fitness for office is relevant. Few personal attributes are more germane to fitness for office than dishonesty, malfeasance, or improper motivation, even though these characteristics may also affect the official's private character. ${ }^{33}$

Statements about morality, prior political affiliations, and personal tastes may also "touch on" the private citizen's fitness to perform his public role. Although Garrison does not compel this reading, it is not an unreal possibility.

Allowing such a wide variety of statements to be made about anyone who fits within the public official category ignores a basic policy of privacy which limits policies of free discussion. As Mr. Justice Stewart noted, concurring in Rosenblatt, the first amendment is not the sole value in the field of defamation.

The right of a man to protection of his own reputation from unjustified invasion and wrongful hurt reflects no more than our basic concept of the essential dignity and worth of every human being. ${ }^{34}$

In order to override this interest in protecting individuals from false defamation about their private lives, there must be a reasonable relationship between what is discussed and how the individual affects the public.

To illustrate this danger of the public official test, suppose that a local roadbuilder with a public contract were accused of being a homosexual. Under the approach used by the courts thus far, the roadbuilder would almost certainly fall under the public official category. The courts would then apply the syllogism they have used in the past: good faith statements about public officials are privileged; this statement is about a public official; therefore, the statement is privileged. Using the suggested relevancy standard, though, the statement would not be privileged. Good faith claims that the roadbuilder is dishonest or incompetent relate directly to his performance as a roadbuilder and thus to his effect on the public at large. Claims about his sexual traits, on the other hand, do not. And because the public has no interest in the private sex life of the roadbuilder, there is no occasion for the first amendment to protect defamatory falsehoods about such topics.

Properly understood, Garrison supports this claim that, to be priv-

33. 379 U.S. 64, 77 (1964).

34. 86 Sup. Ct. at 679 . 
ileged, statements about private characteristics must relate to the individual's public role. In that case, Garrison, a New Orleans District Attorney, was convicted of criminal defamation for castigating local judges who allegedly blocked his investigations of disreputable night spots. He had charged that their actions raised "interesting questions about the racketeer influences on our eight vacation-minded judges." 35

Garrison's statements were made about judges, who are in fact public officials. The Court's catalogue of relevant subjects should be read in this context only. When other kinds of public figures are involved, the Court's reasoning in Garrison requires us to consider different kinds of statements relevant. Unlike the public official, the private citizen is not, by virtue of his presence in the public sphere, a servant of the people; he does not "offer" the totality of his character and personal integrity for judgment. Thus, there will be many aspects of his private life which are irrelevant to his public role. To hold that active private citizens are entitled to no more protection in the law of libel than are public offcials $^{36}$ requires that an individual who enters the public arena give up as much of his private reputation as the public official. ${ }^{37}$ This formulation undercuts the complex and diverse tensions between an individual's right to privacy and the public's right to information. ${ }^{38}$ Moreover, allowing personally defamatory remarks about private individuals would discourage these citizens from speaking out and would thereby subvert the purpose of the first amendment. ${ }^{39}$

A more serious difficulty with focusing on the "public official" category is that speech which the first amendment was designed to protect may be punished. If the court recognizes that the citizen com-

35. 379 U.S. at 66 (1964).

36. See, e.g. Wright, J., concurring in Afro-American Publishing Co. v. JaJje, $-\mathrm{F} .2 \mathrm{~d}$ -, 33 U.S.L. WeEk 2634 (D.C. Cir., May 27, 1965). "When a private citizen enters the public arena, he is entitled to no more protection against libel than a public official."

37. Nowhere does the Rosenblatt opinion recognize the sweeping effect of Garrison in the field of private defamation if all citizens active in public affairs are subject to the same broad relevancy standard as are public officials. The Court's approach continues to assume that the public official approach will strike a proper balance between free discussion and a good reputation.

38. See generally Brandeis \& Warren, The Right to Privacy, 4 HARv. L. REv. 193 (1890).

39. Reisman, Democracy and Defamation: Fair Game and Fair Comment, 42 Coluss. L. REv. 1085, 1088-89 (1942). The danger to free debate in discouraging private citizens from speaking out through fear of private defamation, or lies, did not deter Justice Black from stating in Rosenblatt, for the first time in a court opinion, that all libel laws were barred by the first and fourteenth amendments. 86 Sup. Ct. at 680. See also Cahn \& Black, Justice Black and First Amendment Absolutes; A Public Interiiew, 37 N.Y.U.L. REv. 549, 557 (1962). 
plainant is not a "public official" the court may well refuse to protect the statement regardless of its public nature. The Rosenblatt majority, for example, remanded the case for a new trial at which "the judge ... [will] determine whether the proofs show respondent to be a "public official." "40 Presumably, if the respondent is not found to be a "public official," the statements will be actionable. Thus a columnist making a good-faith statement about the financial affairs of a publicly financed ski resort might be held liable for defamation.

Harper $v$. National Review ${ }^{41}$ is evidence that this possibility is real. In that case the late professor of law at Yale sued the conservative biweekly for an attack on a petition signed by Harper criticizing U.S. policy in Vietnam. The editorial charged that, whether or not the signers were actual Communists, "the objective fact is that these persons we have named, and many others like them have given aid and comfort to the enemies of this country." 42

The court denied defendant's motion to dismiss. In so doing, the court rejected the magazine's contention that "the basic rationale of [Times] is that critics of a public official enjoy a privilege which should be extended to debates on public issues by defenders of the public against persons who speak out on public issues." 43 The court's view was more limited:

"Unlimited, robust, and wide-open debate" of public issues pertaining to public officials does not privilege defamation of private parties by falsehood under the present state of the law. Fair comment needs neither defamation nor falsehood to be robust or informative of the actions of private individuals or to conserve the public interest. No public convenience or necessity appears in the record at this time to require a privilege to defame with falsehood when the debate is among private parties only. ${ }^{44}$

Harper's "public official" test assumes that defamation of any sort about a private person must be private by definition, and that once a person can be located outside the "public official" category, defamatory comment about him cannot be privileged. Thus the court would punish the National Review for publishing its view of how Harper's public statement might affect this country's foreign policy. It is the evident intent of the first amendment to protect this kind of publication.45

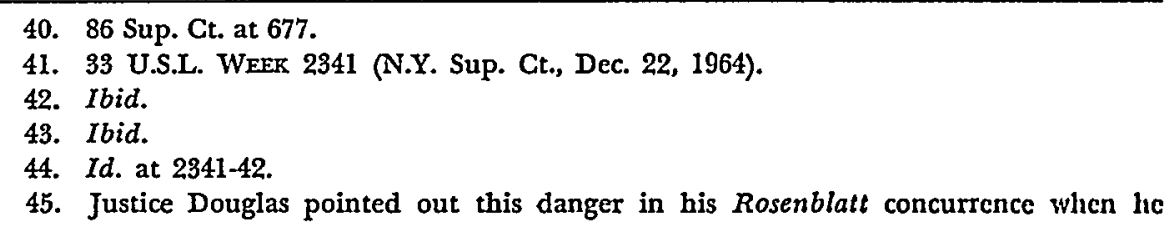


Neither does the "public official" test adequately protect criticism of authors, entertainers, athletes, and a myriad of others who offer their talent for public judgment, but who could not fit into a "public official" category. It would strain that label to the breaking point to include these sorts of "public men." 46 Yet the fair comment doctrine has always recognized that, although separate from the political concerns of the community, the quality of whatever talent or skill these people offer to the public is a legitimate subject for community discussion. Similarly, the first amendment has never been limited to political matters. ${ }^{47}$ Nor is there any reason now to limit the scope of the amendment.

Thus the "public official" test proves too indiscriminate. It may protect too much; or it may protect too little. It neither protects private citizens against unjustified intrusions into their private lives, nor protects the full freedom of speech on public issues demanded by the first amendment. ${ }^{48} \mathrm{~A}$ different approach is needed which better accomplishes these two functions.

The essence of the Times privilege is that citizens may not be punished for good faith statements about public issues. The inquiry in any libel case must, therefore, be directed toward whether the alleged libel concerned a matter legitimately within the public's concern. There are two ways for a matter to come within the public realm. First, a statement may be confined to an issue of public concern without dealing with the private traits of an individual. Second, a statement may in-

said, "so long as we are fashioning a rule of free discussion of public issues, I cannot relate it only to those who, by the Court's standards, are deemed to hold public office. . . The question is whether a public issue, not a public official, is involved." 86 Sup. CL at 678 .

46. See Coleman v. MacLennon, $78 \mathrm{Kan} .711$, at 723, 98 P. 281 at 285 (1903).

47. See, e.g., Jacobellis v. Ohio, 378 U.S. 184, 190 (1964); Roth v. United States, 354 U.S. $476,484,487$ (1957).

48. The refusal of the court to apply broad first amendment grounds may also result in a confusing multiplication of federal limits on state libel laws, rather than limiting federal restrictions to the Constitutional realm. In Linn v. United Plant Guard Workers, 86 Sup. Ct. 657 (1966), the Supreme Court held that the National Labor Relations Act did not bar state courts from hearing libel suits arising out of a union organizing campaign. In order, however, to accommodate "the federal interest in uniform regulation of labor relations with the traditional concern and responsibility of the State to protect its citizens against defamatory attacks," the Court held that, whatever the state libel laws, Linn would would have to prove that he was damaged by the statements and would also have to prove malice. Id. at $660 \mathrm{nn} .2,7$.

This resolution suggests that every time a libel suit arises in an area where the federal government has asserted an interest, different adjustment of state libel laws will have to be made to "accommodate" the federal interests: one for the public official, one for the labor leader, another for the executive of a federally regulated utility, etc. A "public issues" test, on the other hand, would restrict the alteration of state laws to the basic question of whether the subject matter of the speech was within an area protected by the first amendment. 
volve a private trait which is sufficiently relevant to the public role of the complainant to make that trait a public issue.

The first step of the suggested inquiry, then, is for the judge to examine not the status of the complainant but the subject matter of the alleged libel. Using the fair comment doctrine as a guide, ${ }^{40}$ the court should determine first whether the statement was confined to the public arena and directed only at a matter of community concern unaccompanied by personally defamatory comment. If the words complained of were not directed at a private trait of a complainant, the remark must be privileged regardless of the status of the complainant. ${ }^{60}$

Under the first inquiry, the courts need not have undertaken the tangled question of whether Harper, Pearson, or Gilberg were or were not public officials. In each of these cases, the statements were about public issues, and made no reference to a private trait of the complainants. Professor Harper was being chastised for his political position. Clearly, the position which Harper espoused, and therefore criticism of it, was a matter of public concern. The harshness of the criticism did not alter the nature of the remarks. Drew Pearson was attacked solely on the basis of his accuracy and his choice of topics for his column. Again, it seems clear that the quality of news reporting is an issue in which the public has a legitimate interest. None of the statements Pearson complained about were directed at his personal characteristics, but related to him only as he affected the quality of reporting. Complainant Gilberg was simply a member of a law firm which had become a subject of public discussion because one of the partners was the Mayor of the community and there was concern about a possible conflict of interest.

Of course it is possible to draw inferences about private traits from any of these statements. For example Gilberg might claim that statements about his law firm implicated his personal integrity. But almost any statement about a public issue may radiate into someone's private life. If these possible radiations were enough to make criticism action-

49. See text accompanying notes $19-23$, supra. Courts may have to give the determination of what is "public" a somewhat broader definition than that contained in the fair comment doctrine if that doctrine does not properly provide the "breathing space" necessary for the survival of First Amendment frecdoms. N.A.A.C.P. v. Button, 971 U.S. 415,433 (1963).

50. Some good faith misstatements of fact may not be privileged even though thcy do not refer to "private" traits. For example, in trade libel (also known as "injurious falsehood," "disparagement of property," "slander of goods") where the business is not a matter of public concern aspersions on the quality of a product or the character of a business and statements that a businessman has died or gone out of business, among others, are actionable. See Prosser, Torts $938-50$ (3d ed. 1964). 
able, the Times privilege would be meaningless. In order to make a statement suspect the implication about private traits should be necessary and direct. One part of the Rosenblatt opinion dealt with an analogous problem. Baer claimed that Rosenblatt's column which criticized the performance of the publicly-owned local ski resort's previous management could be read as an attack on Baer's personal honesty since Baer was one of the former managers. Mr. Justice Brennan rejected this contention, and, relying on Times, he held that "[ $t]$ here must be evidence showing that the attack was read as specifically directed at plaintiff [Baer]." 51 Brennan went on to explain,

Were the statement at issue in this case an explicit charge that the Commissioners and Baer or the entire area management were corrupt, we assume without deciding that any number of the identified group might recover. The statement itself might be sufficient evidence that the attack was specifically directed at each individual. Even if a charge and reference were merely implicit, as it is alleged here, but a plaintiff could show by extrinsic proofs that the statement referred to him, it would be no defense to a suit by one member of an identifiable group engaged in governmental activity that another was also attacked. These situations are distinguishable from the present cases; ... . Here, no explicit charge of peculation was made; no assault on the previous management appears. The jury was permitted to award damages upon a finding merely that respondent was one of a small group acting for an organ of government, only some of whom were implicated, but all of whom were tinged with suspicion. In effect, this permitted the jury to find liability merely on the basis of his relationship to the government agency, the operations of which were the subject of discussion. It is plain that the elected Commissioners, also members of that group, would have been barred from suit on this theory under... Times. They would be required to show specific reference. Whether or not respondent was a public official, as a member of the group he bears the same burden. A theory that the column casts indiscriminate suspicion on the members of the group responsible for the conduct of this government operation is tantamount to a demand for recovery based on libel of government, and therefore is constitutionally insufficient. ${ }^{62}$

By similar reasoning a statement about a public issue should be actionable only when a complainant makes a strong showing that the statement was directed at or necessarily implied a criticism of a private trait. $^{53}$ If this test is met, the courts should then ask whether the com-

51. 86 Sup. Ct. at 673 .

52. Id. at 673-74.

53. This approach would thus privilege the statements in the Gilberg and Pearson cases, as did the court's. But it would avoid the identification of all public citizens as 
plainant has assumed any public role ${ }^{54}$ and whether the trait discussed is relevant to that role. Here too, the fair comment doctrine provides some guidelines. In a series of cases involving authors, entertainers, businessmen, and other public figures, the courts have generally held that critics may not "follow into ... domestic life" but have wide latitude in dealing with personal characteristics which have a definite relation to the public role being performed. ${ }^{55}$

It is, of course, possible to imagine arguments which would make any private trait relevant to any public role. The defendant in the hypothetical case involving a roadbuilder falsely accused of homosexuality could allege that homosexuality indicates immorality; that immorality might manifest itself in other ways, for example, dishonesty; and that the public's right to know about dishonest roadbuilders falls within the area of protected first amendment criticisms. The judgment of relevance, though, should be much more stringent. The courts should demand that the defendant show a relationship on the basis of evidence and not on the basis of an artificially, albeit imaginatively, constructed connection. The injury to individuals and to the climate of public discussion is too great to permit personally defamatory falsehood to go unpunished when no overriding public interest is served.

An example of a case where the relevancy standard might apply is Dempsey v. Time, Inc.56 The former heavyweight champion sued Sports Illustrated Magazine for an article which alleged that Dempsey's trainer had "loaded" his gloves with plaster of paris, enabling him to win the championship in 1919. The court thought that the Times privilege might well extend to "current issues of grave public concern," but added

public officials-an identification which might well have undesirable results. Sce text accompanying notes 34-41, supra.

54. The determination of whether complainant occupied a public role might involve a determination similar to that performed by courts in judging whether or not a plain. tiff was a public official. However, the determination of "public role" is made only after it has been found that the statement contained a private defamation. Thus the courts avoid the danger in the public official approach that statements on purcly public issucs would be made actionable. See text accompanying notes 43-47, supra. Further, the strict standards of relevancy to be applied will allow courts to make a more honest inquiry into the complainant's public role since he will not be subject to a wide variety of private defamations.

55. See generally Hallen, Fair Comment, 8 Texas L. REv. 41 (1929), and cases compiled therein. For an amusing and celebrated example, see Cherry v. Des Moines Leader, 114 Iowa 298, 86 N.W. 323 (1901).

56. 43 Misc. 2d 754, 252 N.Y.S.2d 186 (Sup. Ct., 1964). 
... that the reaching back 45 years, as was done in the instant case, is not within the purview of even the suggested extension. ... This court is not prepared to hold that because of the mere fact that one is a public individual he may be exposed to naked libel. ... .57

The time element cited by the court does not take the statement out of the public issue category. Historical events, in and out of the political world, may continue to be of public interest, and new light on a wellknown athletic contest cannot be said to be outside the ambit of constitutional protection. That phase of the subject-matter, at least, should be well within the protected area of discussion. However, in this case it is possible that the statement, although directed to a discussion of a public issue, also could be read as casting aspersions on Dempsey's personal integrity. The statement could be read sensibly as impugning Dempsey's personal honesty and accusing him of participating in an immoral scheme rather than as criticizing his punching ability or footwork. This reading is neither strained nor unreal.63

Since the court would find defamation of a personal nature in Dempsey it would then have to determine the relevancy of the remark to Dempsey's public role. The court would find that the statement bore the most direct relationship to that phase of Dempsey's life "offered" for public scrutiny, his performance as a prize fighter. Dempsey himself had created a legitimate public interest by performing for public attention and financial reward. Thus, absent a finding of actual malice, the privilege should apply.

The court's role in applying the Times privilege within the already tangled field of defamation ${ }^{59}$ will not be easy, particularly in determining relevancy. There is a wide variety of private citizens active in the public arena. In addition to public figures, commentators, and entertainers, those who run large businesses or labor unions, and those who operate quasi-public institutions such as charities and foundations

\section{43 Misc. $2 \mathrm{~d}$ at 756-57.}

58. Dempsey illustrates the possibility that a statement may involve both a public issue and a private trait. For example, suppose the defendant in the roadbuilder case had said, " $X$ ought not to get the construction contract, because the last road he built cracked and he is a homosexual." Although the remark was about a public issue (who should get the contract) and it was in part public (the builder's competency), it also contained a defamation about an irrelevant private trait. In such a case, the court must clearly hold that part of the statement which was private actionable. Othervise every private defamation would be privileged as long as the speaker had included it within a general discussion of a public issue.

59. See Prosser, Torts, § 106, p. 754 (3d ed. 1964). 
all have a massive impact on society. ${ }^{00}$ Moreover, as a result of government's increasing involvement in the nation's economic and social life, the public has an interest in an ever-widening sphere of activities. ${ }^{01}$ Private organizations frequently receive large sums of money through government contracts or subsidies. Occupations are subject to public supervision. The applicability of the first amendment to these figures should be clear; Coleman v. MacLennon, ${ }^{62}$ a case on which both Times and Garrison rely, noted that the privilege "extends to a great variety of subjects and includes matters of public concern ... (and) public men." 63

In each case, relevancy must be determined by the involvement in and effect on community life. This inquiry is not simple; nor is it certain. It is, however, the most promising method of giving life to the first amendment command that public issues are committed to the citizenry for full and free discussion.

60. See generally, Reich, The New Property, 73 Yals L.J. 733 (1964).

61. The suggested approach would thus cover cases like Linn, note 48 supra:

Surely the public importance of collective bargaining puts labor as well as management into the public arena so far as the present constitutional issue is concerned.

Douglas, J., concurring in Rosenblatt v. Baer, 86 Sup. Ct. at 677.

62. $78 \mathrm{Kan} .711,98$ P. 281 (1908).

63. 78 Kan. at 723, 98 P. at 285. See also Pedrick, Freedom of the Press and the Law of Libel: The Modern Revised Translation, 49 CoRNeLL L.Q. 587 (1964); Comment, 12 U.C.L.A. L. REv. 1420 (1965). 